\title{
Citation of the Bacteriological Code (1975 Revision)
}

It has been pointed out (1) that there are inconsistencies in the citation of the date of the International Code of Nomenclature of Bacteria. (2). The current revision of the Bacteriological Code was both copyrighted and published in 1975. Furthermore, rule la states that this revision should be cited as the 1975 Revision and that it was to apply "from the date of publication (1 January 1976)." Clearly, the intent was to have the code available before 1 January 1976, so that it could become effective on that date. Therefore, the terms "Bacteriological Code 1976 Revision" on the title page and "Bacteriological Code 1976" on the spine of the book are in error. The correct citation remains "Bacteriological Code (1975 Revision)," as directed by rule 1a.

REPRINT REQUESTS

Address reprint requests to: L. G. Wayne, Veterans Administration Medical Center, Long Beach, CA 90822.

\section{LITERATURE CITED}

1. Farmer, J. J., D. J. Brenner, and W. H. Ewing. 1980. Opposition to recent proposals which would reject the family name Enterobacteriaceae and Escherichia as its type genus. Int. J. Syst. Bacteriol. 30:660-673.

2. Lapage, S. P., P. H. A. Sneath, E. F. Lessel, V. B. D. Skerman, H. P. R. Seeliger, and W. A. Clark (ed.). 1975. International code of nomenclature of bacteria 1975 Revision. American Society for Microbiology, Washington, D.C.

L. G. Wayne

Chairman, Judicial Commission 